\title{
Ventromedial Prefrontal Cortex Pyramidal Cells Have a Temporal Dynamic Role in Recall and Extinction of Cocaine-Associated Memory
}

\author{
Michel C. Van den Oever, ${ }^{1}$ Diana C. Rotaru, ${ }^{2}$ Jasper A. Heinsbroek, ${ }^{1}$ Yvonne Gouwenberg, ${ }^{1}$ Karl Deisseroth, ${ }^{3}$ \\ Garret D. Stuber, ${ }^{4,5}$ Huibert D. Mansvelder, ${ }^{2}$ and August B. Smit ${ }^{1}$ \\ Departments of ${ }^{1}$ Molecular and Cellular Neurobiology and ${ }^{2}$ Integrative Neurophysiology, Center for Neurogenomics and Cognitive Research, Neuroscience \\ Campus Amsterdam, VU University Amsterdam, 1081 HV, The Netherlands, ${ }^{3}$ Department Bioengineering, Stanford University School of Medicine, \\ Stanford, California 94305, Departments of ${ }^{4}$ Psychiatry and ${ }^{5}$ Cell Biology and Physiology, UNC Neuroscience Center, University of North Carolina at Chapel \\ Hill, Chapel Hill, North Carolina 27599
}

In addicts, associative memories related to the rewarding effects of drugs of abuse can evoke powerful craving and drug seeking urges, but effective treatment to suppress these memories is not available. Detailed insight into the neural circuitry that mediates expression of drug-associated memory is therefore of crucial importance. Substantial evidence from rodent models of addictive behavior points to the involvement of the ventromedial prefrontal cortex (vmPFC) in conditioned drug seeking, but specific knowledge of the temporal role of vmPFC pyramidal cells is lacking. To this end, we used an optogenetics approach to probe the involvement of vmPFC pyramidal cells in expression of a recent and remote conditioned cocaine memory. In mice, we expressed Channelrhodopsin-2 (ChR2) or Halorhodopsin (eNpHR3.0) in pyramidal cells of the vmPFC and studied the effect of activation or inhibition of these cells during expression of a cocaine-contextual memory on days 1-2 (recent) and $\sim 3$ weeks (remote) after conditioning. Whereas optical activation of pyramidal cells facilitated extinction of remote memory, without affecting recent memory, inhibition of pyramidal cells acutely impaired recall of recent cocaine memory, without affecting recall of remote memory. In addition, we found that silencing pyramidal cells blocked extinction learning at the remote memory time-point. We provide causal evidence of a critical time-dependent switch in the contribution of vmPFC pyramidal cells to recall and extinction of cocaine-associated memory, indicating that the circuitry that controls expression of cocaine memories reorganizes over time.

\section{Introduction}

Treatment of drug addiction is hampered by the recurrent desire of addicts to use drugs despite negative consequences. Environmental cues (e.g., locations, paraphernalia) have a pivotal role in the initiation and maintenance of addictive behavior. During drug intake, these cues become associated with the rewarding effects of the drug and thereby acquire salient properties that can vigorously trigger drug craving and drug-seeking responses (Grant et al., 1996; Childress et al., 1999). It is therefore of crucial importance to have a detailed understanding of the neural circuitry that controls expression of conditioned drug seeking and

Received June 7, 2013; revised Sept. 24, 2013; accepted 0ct. 10, 2013

Author contributions: M.C.V.d.O., H.M., and A.B.S. designed research; M.C.V.d.O., D.R., J.H., and Y.G. performed research; K.D. and G.D.S. contributed unpublished reagents/analytic tools; M.C.V.d.O., D.R., and J.H. analyzed data; M.C.V.d.O., G.D.S., H.M., and A.B.S. wrote the paper.

This research is funded by a NWO/ZonMW Veni grant and by a Brain and Behavior Research Foundation Young Investigator Award (18310) to M.C.V.d.O. We thank T.J. De Vries for valuable comments on this manuscript.

The authors declare no competing financial interests.

Correspondence should be addressed to Michel C. Van den Oever, Department of Molecular and Cellular Neurobiology, CNCR, Neuroscience Campus Amsterdam, Vrije Universiteit, De Boelelaan 1085, 1081 HV Amsterdam, The Netherlands. E-mail: michel.vanden.oever@vu.nl.

DOI:10.1523/JNEUROSCI.2412-13.2013

Copyright $\odot 2013$ the authors $\quad 0270-6474 / 13 / 3318225-09 \$ 15.00 / 0$ to identify potential cellular subtypes that are able to suppress expression of drug-associated memories.

Accumulating evidence from rodent models of conditioned drug seeking points to the involvement of the ventral region of the mPFC (vmPFC) (Peters et al., 2009; Van den Oever et al., 2010a), comprising the ventral prelimbic cortex and infralimbic cortex (Heidbreder and Groenewegen, 2003). Pharmacological inactivation of vmPFC neurons attenuates expression of conditioned cocaine and heroin seeking (Rogers et al., 2008; Koya et al., 2009a), and cue-induced reinstatement of heroin seeking is associated with acute synaptic depression of vmPFC pyramidal cells (Van den Oever et al., 2008). Substantial evidence also implicates the vmPFC in extinction of conditioned responding to aversive as well as appetitive cues (Milad and Quirk, 2002; Peters et al., 2009). Extinction is induced by non-reinforced exposure to conditioned cues and is thought to result in the formation of a new memory trace that suppresses expression of the conditioned response. Recent findings support involvement of the vmPFC in learning of extinction of conditioned cocaine seeking (LaLumiere et al., 2010; LaLumiere et al., 2012), as well as retrieval of extinction memory after cocaine and heroin seeking is extinguished (Ovari and Leri, 2008; Peters et al., 2008a). The seemingly contradictive role of the vmPFC in recall and extinction stresses the 
need to define the temporal contribution of specific cellular subtypes to the expression of conditioned drug memory. Neuronal subtypes that reside within the rodent neocortex can approximately be divided into glutamatergic pyramidal cells and GABAergic interneurons (Beaulieu, 1993; Somogyi et al., 1998). Pyramidal cells account for $\sim 80 \%$ of all neurons within the rodent vmPFC (Bossert et al., 2011) and, importantly, are the primary source of efferent projections to target regions (Sesack et al., 1989). Therefore, vmPFC pyramidal cells are thought to strongly contribute to addictive behavior, but causal evidence that their activity controls conditioned drug seeking, as well as insight into the temporal involvement of pyramidal cells to recall and extinction, is lacking. The use of optogenetic tools allowed us to probe the contribution of vmPFC pyramidal cells to expression of a recent and remote conditioned cocaine memory with high temporal precision in freely moving mice. Our data demonstrate that pyramidal cells in the vmPFC have a dynamic time-dependent role in recall of cocaine-associated memory and the formation of an inhibitory extinction memory.

\section{Materials and Methods}

Mice. Male transgenic C57BL/6 CaMKII::Cre mice (expressing Crerecombinase under control of the $\mathrm{Ca}^{2+} /$ calmodulin-dependent protein kinase II $\alpha$ promoter) and male wild-type C57BL/6 mice (Charles River) aged $2-3$ months at the start of experiments were individually housed on a $12 \mathrm{~h}$ light/dark cycle. Food and water were available ad libitum throughout the experiment. The animal ethical care committee of the VU University Amsterdam approved all experiments.

Opsin virus delivery and chronic implantation of optic fiber. Cre-inducible adeno-associated viral (AAV) opsin constructs pAAV-DIO-ChR2(H134R)EYFP, pAAV-DIO-eNpHR3.0-EYFP, and pAAV-DIO-EYFP (Tsai et al., 2009) and CaMKII $\alpha$ promoter-driven opsin plasmids pAAV-CaMKII $\alpha::$ ChR2(H134R)-EYFP, pAAV-CaMKII $\alpha::$ NpHR3.0-EYFP, and pAAVCaMKII $\alpha:$ :EYFP (Tye et al., 2011) were packaged as AAV serotype 2 virus (titers: $1.0-6.0 \times 10^{12}$ ). Mice were anesthetized with isoflurane, received 0.1 $\mathrm{mg} / \mathrm{kg}$ Temgesic (RB Pharmaceuticals) and were mounted in a stereotactic frame. Microinjection glass needles were inserted into the vmPFC $[+2.2$ $\mathrm{mm} \mathrm{AP} ; \pm 0.4 \mathrm{~mm} \mathrm{ML} ;-3.0 \mathrm{~mm} \mathrm{DV}$; relative to bregma], and $0.5 \mu$ l of virus was infused over $5 \mathrm{~min}$ followed by an additional $5 \mathrm{~min}$ to allow diffusion of the virus. Next, an optical fiber [105 $\mu \mathrm{m}$ core for channelrhodopsin-2 (ChR2) experiments, $200 \mu \mathrm{m}$ core for halorhodopsin (eNpHR3.0) experiments (Sparta et al., 2012)] was chronically implanted directly above the $\operatorname{vmPFC}(-2.6 \mathrm{~mm}$ DV; relative to bregma). In eNpHR3.0 and respective control mice, virus was bilaterally infused in the vmPFC and a single optic fiber was implanted between both vmPFC hemispheres (Goshen et al., 2011). Optical fibers were fixed to the skull using Simplex Rapid dental cement (Kemdent) and covered with a protective cap until use. Mice remained in their home-cage for 3-5 weeks until the start of experiments.

CPP apparatus and paradigm. Conditioning took place in a custommade CPP apparatus that consisted of three compartments with the two outer compartments differing in visual and tactile cues. Place conditioning proceeded in the following three sequential phases: preconditioning test, conditioning, and postconditioning tests. First, baseline preferences were determined in the preconditioning test by allowing the mice free access to all compartments of the CPP apparatus for $10 \mathrm{~min}$. The drugpaired and saline-paired compartments were randomized and counterbalanced across all groups to allow an unbiased CPP procedure. Conditioning sessions were conducted twice daily for 3 subsequent days, with a minimum of $5 \mathrm{~h}$ between conditioning sessions. For each conditioning session, mice were confined to one of the two compartments for 15 min immediately following administration of saline (morning, intraperitoneally) or cocaine (afternoon; $15 \mathrm{mg} / \mathrm{kg}$, i.p.). Place preference was assessed in postconditioning tests by allowing the mice free access to all compartments for $5 \mathrm{~min}$ under drug-free conditions. Time spent in each compartment was measured with a video camera that was interfaced to a computer equipped with Ethovision video-tracking software (Noldus). During each postconditioning test, mice were connected to an optic fiber patch cable coupled to a steady-state laser (Shanghai Laser and Optics Century Company). ChR2 was activated using a $473 \mathrm{~nm}$ laser with the following parameters: $3 \mathrm{~mW}, 10 \mathrm{~ms}$ pulse, train of 5 pulses at $20 \mathrm{~Hz}$ each second for $5 \mathrm{~min}$. Activation of pyramidal cells was always performed in trains of 5 pulses at $20 \mathrm{~Hz}$, as we found that continuous stimulation at 20 $\mathrm{Hz}$ induced seizure-like behavior in some animals. Optic activation of eNpHR3.0 was performed using a $532 \mathrm{~nm}$ laser, $10 \mathrm{~mW}$, continuous stimulation over $5 \mathrm{~min}$. To minimize stray light in the CPP box, optic fiber patch cables were covered with black furcation tubing (Precision Fiber Products) and the head fiber-patch cable connection was shielded with a black plastic tube. CaMKII::Cre mice infused with Cre-inducible opsin virus were used for experiments in Figures 3 and $5 A$. Due to problems with the breeding of CaMKII::Cre mice, wild-type mice infused with CaMKII $\alpha$ promoter-driven opsin virus (Goshen et al., 2011; Stuber et al., 2011) were used in all other experiments.

In graphs, preference scores reflect the time spent in the cocainepaired compartment minus time spent in the saline-paired compartment. For statistical analyses, data were subjected to a repeated-measures ANOVA to detect interactions between group, effect of optic stimulation, and effect of time-point of CPP tests. In case of significant interactions, CPP scores were subjected to Student's $t$ tests to detect between-group differences for each test.

Whole-cell recordings. Mice were decapitated and brains quickly removed and immersed in ice-cold, modified ACSF containing the following (in mM): $125 \mathrm{NaCl}, 3 \mathrm{KCl}, 1.25 \mathrm{NaH}_{2} \mathrm{PO}_{4}, 2 \mathrm{MgSO}_{4}, 1 \mathrm{CaCl}_{2}, 26$ $\mathrm{NaHCO}_{3}$, and 10 glucose, pH 7.3-7.4 when bubbled with $95 \% \mathrm{O}_{2}-5 \%$ $\mathrm{CO}_{2}$. Next, coronal PFC slices $(300 \mu \mathrm{m})$ were made and immediately placed in an incubation chamber filled with normal ACSF. Slices were stabilized at room temperature in the same solution for at least $60 \mathrm{~min}$ before they were transferred to the recording chamber. The recording chamber was superfused at a flow rate of $2 \mathrm{ml} / \mathrm{min}$ with normal ACSF. Whole-cell voltage and current-clamp recordings of pyramidal cells were made using a Multiclamp 200 B amplifier. Patch electrodes (3.0-5.0 $\mathrm{M} \Omega$ ) were backfilled with internal solution containing the following (in mм): K-gluconate 120, $\mathrm{NaCl}$ 10, HEPES 10, EGTA 0.2, MgATP 4.5, NaGTP 0.3 , and Na-phosphocreatine 14 , and the $\mathrm{pH}$ was adjusted to 7.2-7.4 using $\mathrm{KOH}$. Cells were visualized using infrared differential interference contrast and viral expression was identified using fluorescence microscopy. For optical stimulation, an optic fiber was placed within 50 $\mu \mathrm{m}$ from the recording electrode. Cells were voltage clamped at $-70 \mathrm{mV}$ to test the presence of the ChR2-mediated excitatory currents and to determine spike fidelity. To determine eNpHR3.0-mediated currents, cells were voltage clamped at $-70 \mathrm{mV}$. Next, cells were depolarized to $-55 \mathrm{mV}$ to assess whether eNpHR3.0 activation decreased firing probability of pyramidal cells. All data were filtered at $3 \mathrm{kHz}$, digitized, and collected using pClamp10 software (Molecular Devices).

Immunohistochemistry. Mice were transcardially perfused with icecold PBS pH 7.4 followed 4\% paraformaldehyde (PFA) in PBS, pH 7.4. Brains were postfixed in 4\% PFA overnight and immersed in 30\% sucrose in PBS, pH 7.4, for 3-4 d. Brains were sliced coronal $(35 \mu \mathrm{m})$ on a cryostat and stored in PBS with $0.02 \% \mathrm{NaN}_{3}$ at $4^{\circ} \mathrm{C}$ until further use. Immunofluorescence staining was performed using standard protocols (Van den Oever et al., 2010b) using the following primary antibodies: rabbit anti-Fos (1:5000; Millipore), mouse anti-CaMKII (1:400; Thermo Scientific), mouse anti-GAD67 (1:1000; Millipore), and Neurotrace 530/ 615 Red. Brain slices were analyzed by confocal microscopy (LSM 510, Zeiss). For quantification of Fos ${ }^{+}$cells in vmPFC and dmPFC, $z$-stacks were generated of four brain sections per mouse.

\section{Results}

\section{ChR2 expression and optic stimulation of pyramidal} cell firing

We first assessed the effect of increasing vmPFC pyramidal cell activity during expression of conditioned cocaine memory. To allow the selective activation of pyramidal cells, we unilaterally micro-injected Cre-inducible AAV2 virus encoding ChR2 fused to enhanced yellow fluorescent protein (EYFP) in the vmPFC of CaMKII::Cre mice. Using these vectors, opsin expression can be 

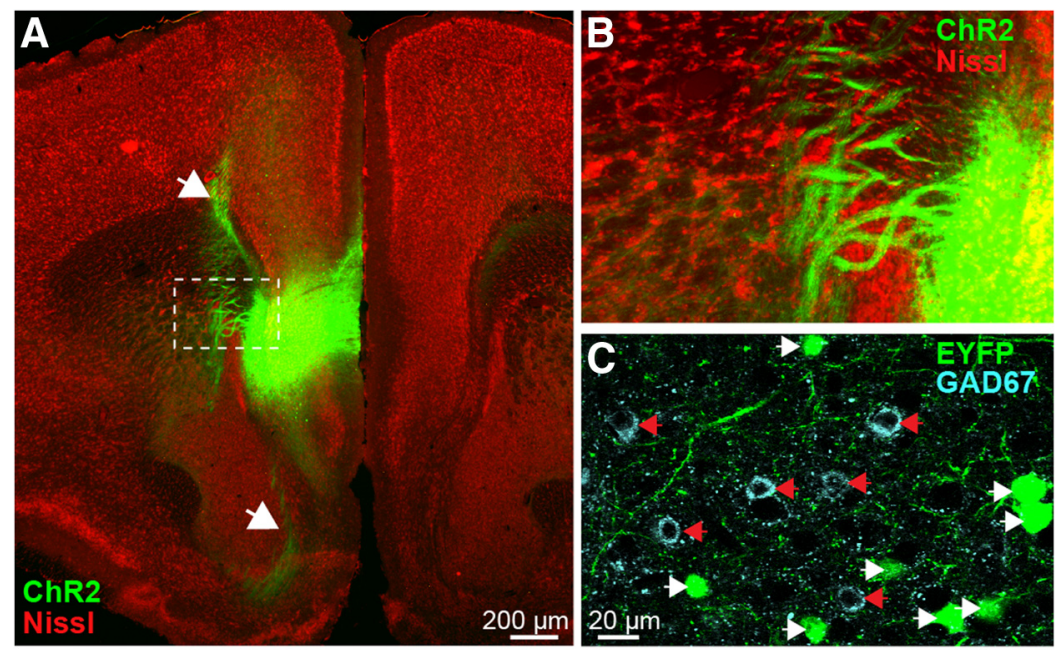

D

\section{EYFP}

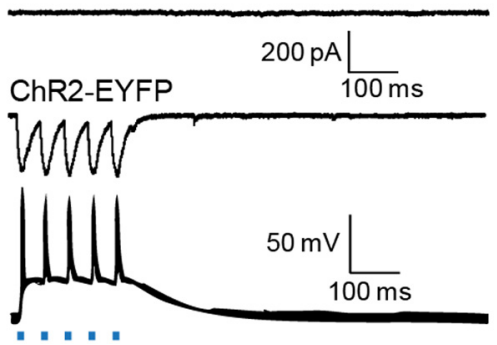

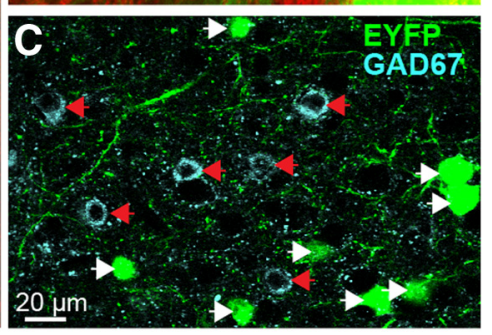

E

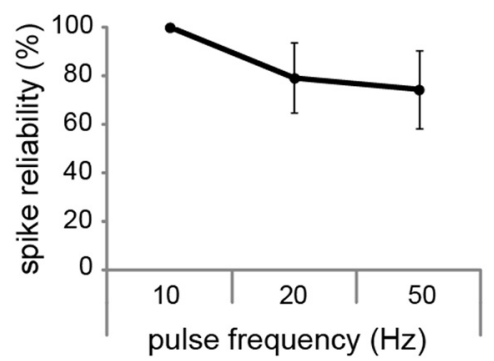

Figure 1. ChR2 expression and optic stimulation of vmPFC pyramidal cells. $\boldsymbol{A}$, Representative Nissl (red) stained image of a coronal brain slice with ChR2-EYFP expression (green) in the vmPFC. White arrows indicate projection targets of ChR2-EYFPexpressing cells. fmi, Forceps minor of the corpus callosum. $\boldsymbol{B}$, Magnification of dashed boxed area in $\boldsymbol{A}$, showing bundles of axonal fibers projecting from vmPFC pyramidal cells into the forceps minor corpus callosum. C, EYFP ${ }^{+}$cells (green; white arrows) did not colocalize with $\mathrm{GAD} 67^{+}{ }^{+} \mathrm{GABAergic}$ interneurons (blue; red arrows). D, Acute brain slice recording of a ChR2 ${ }^{+}$and control (EYFP only) pyramidal cell. Pulses of blue light evoked robust inward currents and spike firing in ChR2 ${ }^{+}$cells, but not control cells. Traces (1 s) are an overlay of 300 consecutive recordings (over $5 \mathrm{~min}$ ) of a single cell. $\boldsymbol{E}$, Average spike fidelity in current-clamped ChR2-EYFP ${ }^{+}$cells $(n=5)$ with increasing pulse frequencies. Data represent mean \pm SEM.

targeted to cells expressing Cre-recombinase under control of a cell type-specific promoter region with great specificity and minimal leakage to other cell types (Tsai et al., 2009; van Zessen et al., 2012). Histological analysis showed that ChR2-EYFP expression was predominantly restricted to neurons of the infralimbic cortex, with some expression in neurons of the ventral prelimbic cortex and dorsal peduncular cortex (Fig. 1A). As the dorsal peduncular cortex contributes in a similar manner as the infralimbic cortex to the extinction of cocaine seeking (LaLumiere et al., 2012), we included mice with ChR2 expression in this region in all analyses. ChR2-EYFP was localized in fiber tracts projecting via the forceps minor corpus callosum to the dorsal mPFC and nucleus accumbens (Fig. 1B), confirming that ChR2-EYFP was indeed expressed in the excitatory pyramidal cells previously described to innervate these regions (Heidbreder and Groenewegen, 2003; Voorn et al., 2004). To determine whether viral expression was absent in GABAergic interneurons, we infused Cre-inducible EYFP control virus in the vmPFC of CaMKII-cre mice (individual cell bodies were difficult to identify with ChR2 virus). We did not observe colocalization between $\mathrm{EYFP}^{+}$cells and GAD $67^{+}$neurons $(0.0 \% ; n=5$ mice) in the vmPFC (see also Fig. $1 C$ ), indicating that viral expression did not occur in GABAergic interneurons and was restricted to putative pyramidal cells.

Next, we determined whether ChR2 was expressed at levels that would allow optic activation of pyramidal cells with pulses of blue light (473 nm). Whole-cell recordings from visually identified ChR2-EYFP expressing vmPFC pyramidal cells in acute brain slices showed that light pulses (10 ms pulse, train of 5 pulses at $20 \mathrm{~Hz}$ each second for a total of $5 \mathrm{~min}$ ) reliably induced inward currents and spike firing time-locked to the light pulses (Fig. 1D). Using this optic stimulation protocol, we found minimal loss of spike fidelity with light frequencies up to $50 \mathrm{~Hz}$ (Fig. 1E). Together, these findings demonstrate that optic stimulation induced sustained firing of pyramidal cells at frequencies that have previously been observed in vivo (Sun et al., 2011).

\section{Optic activation of vmPFC pyramidal cells in vivo}

To enable optic stimulation in awake, behaving animals, we unilaterally expressed ChR2-EYFP or EYFP only (control) in vmPFC pyramidal cells and equipped mice with a chronic optic fiber implant directly above the vmPFC. First, we determined whether in vivo optic stimulation selectively increased neuronal activity in the vmPFC, but not dmPFC (dorsal prelimbic cortex/anterior cingulate cortex), as these regions are thought to be differentially involved in conditioned cocaine seeking (Peters et al., 2009; Van den Oever et al., 2010a). Mice were allowed to recover from surgery for 4 weeks and then received optic stimulation in their home cage for $3 \mathrm{~min}[3 \mathrm{~mW}, 20 \mathrm{~Hz}$ in a train of 5 pulses each second (same parameters as above)]. We used $20 \mathrm{~Hz}$ stimulation as it was previously found that mPFC pyramidal cells fire with this frequency during recall of morphine-conditioned place preference memory (Sun et al., 2011) and $20 \mathrm{~Hz}$ optogenetic stimulation of pyramidal cells in various brain regions has been shown to produce behaviorally relevant effects (Johansen et al., 2010; Stuber et al., 2011). Animals were perfused $90 \mathrm{~min}$ after the start of stimulation and brain sections were immunostained for Fos, a widely used marker for recent neuronal activity (Reijmers et al., 2007; Koya et al., 2009b; Fig. 2). ANOVA including the factors brain region and groups revealed a significant brain region and brain region $\times$ group interaction $\left(F_{(1,8)}=36.8, p<0.001\right)$. Optic stimulation induced a significant $\left(t_{(2)}=-12.8 p=0.001\right)$ increase in the number of Fos-expressing cells in the vmPFC of ChR2 mice compared with control mice, but not in the dmPFC $\left(t_{(2)}=0.74, p=0.51\right)$. This indicates that using our optic stimulation conditions, we selectively activated pyramidal cells in the vmPFC.

\section{Activation of pyramidal cells during expressing of recent and} remote conditioned-cocaine memory

Using an unbiased conditioned place preference (CPP) paradigm, CaMKII::Cre mice expressing ChR2 or EYFP (control) in the vmPFC were trained to associate one of two different contexts with the rewarding effects of cocaine. We determined whether vmPFC pyramidal cells are involved in the expression of conditioned 
cocaine-seeking at two time-points: (1) at days 1 and 2 after conditioning (recent memory) and (2) at days 21 and 22 after conditioning (remote memory). Preference for the cocaine-associated context was determined in the presence of optic stimulation (see parameters above) of vmPFC pyramidal cells (days 1 and 21) and in the absence of it (days 2 and 22; Fig. 3A). Tests were performed for a duration of $5 \mathrm{~min}$ to minimize the induction of extinction mechanisms. A split-plot repeatedmeasures ANOVA with within-subject factors "light" (on vs off) and "timepoint" (recent vs remote) and betweensubject factor "group" (ChR2 vs EYFP) revealed a significant light $\times$ time-point $\left(F_{(1,12)}=9.05, p=0.011\right)$ and light $\times$ time-point $\times$ group interaction $\left(F_{(1,12)}=\right.$ $5.14, p=0.043)$, but no significant effect for group, light or group $\times$ light. Additional analyses demonstrated that preference scores differed between groups at Test 4 only $\left(t_{(12)}=3.94, p=0.004\right)$. Thus, activation of pyramidal cells had no effect on the expression of conditioned cocaine seeking at the recent memory time-point and no acute effect during the remote "light on" test, but subsequently impaired expression of CPP memory during the remote "light off" test. Importantly, repeated-measures analysis of locomotor activity during CPP tests revealed a significant effect of light $\left(F_{(1,12)}=34.1 ; p<\right.$ $0.001)$, but no group, group $\times$ light, or group $\times$ light $\times$ timepoint effect, indicating that activation of pyramidal cells did not impair motor performance.

The observed reduction in expression of conditioned cocaine memory at the remote light off test may have been the result of repeated testing and optic stimulation at the recent and remote memory time-points. To determine whether the effect was specific for the remote CPP memory time-point, we assessed the effect of activating pyramidal cells at this time-point only. For this experiment and all other experiments shown in Figure 4, we used wild-type mice infused with $\mathrm{CaMKII} \alpha$ promoter-driven ChR2 and EYFP viral constructs (see Materials and Methods). First, we determined whether this approach also resulted in viral expression in pyramidal cells by examining coexpression with GAD67 (Fig. 4A). We found minimal colocalization of GAD67 within the $\mathrm{EYFP}^{+}$cell population $(5.6 \%)$, indicating that the large majority $(94.4 \%)$ of $\mathrm{EYFP}^{+}$neurons were putative pyramidal cells. As vmPFC GABAergic cells are local interneurons and pyramidal cells send excitatory output to other brain regions, optic activation of pyramidal cells should result in activation of neurons in downstream target regions of the vmPFC. To confirm that we indeed activate pyramidal cells in vivo using this approach, we optically stimulated mice in their home-cage (similar to above) and analyzed Fos expression in two primary target areas of the vmPFC, the medial region of the nucleus accumbens core and shell (Voorn et al., 2004). ANOVA including the factors brain area and group only revealed a significant effect of group $\left(F_{(1,22)}=\right.$ $10.28, p=0.004)$, with ChR2 mice exhibiting a significant increase in the number of Fos-expressing cells within the nucleus accumbens core $\left(t_{(11)}=2.53, p=0.028\right)$ and a strong trend in the shell $\left(t_{(11)}=2.15, p=0.054\right)$. Hence, similar to the Cre-inducible

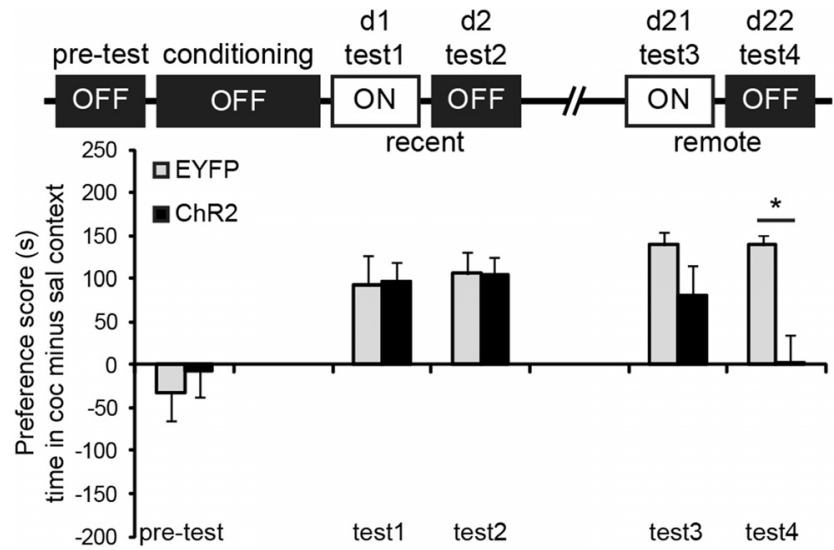

Figure 3. Activation of pyramidal cells facilitated extinction of remote CPP memory. Activation of pyramidal cells did not affect expression of recent cocaine (PP memory (Test $1+2$ ) and had no acute effect on recall of remote (PP memory (Test 3), but remote (PP memory was abolished when ChR2 mice were subsequently tested without optic stimulation of pyramidal cells (Test 4). ${ }^{*} p=0.004$ compared with control group. ChR2, $n=8$; EYFP, $n=6$ mice.

opsin viruses, we primarily target pyramidal cells using the CaMKII promoter-driven virus approach, and optic stimulation resulted in increased output from these cells to downstream projection regions. Next, we trained a group of ChR2 and control mice and assessed the effect of optic stimulation of pyramidal cells in two light on/light off trials at the remote CPP memory time-point (days 24-27 after conditioning; Fig. 4C). Repeatedmeasures ANOVA revealed a significant light $\left(F_{(1,17)}=7.43\right.$, $p=0.014)$, trial $\left(F_{(1,17)}=15.1, p=0.001\right)$, and light $\times$ group interaction $\left(F_{(1,17)}=5.08, p=0.038\right)$, but no significant light $X$ trial $\times$ group interaction, indicating that activation of pyramidal cells reduced expression of conditioned cocaine memory in the ChR2 group in both trials. Moreover, both groups showed reduced preference for the cocaine-associated context in Trial 2 
A

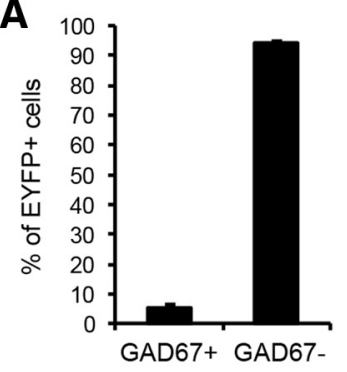

B
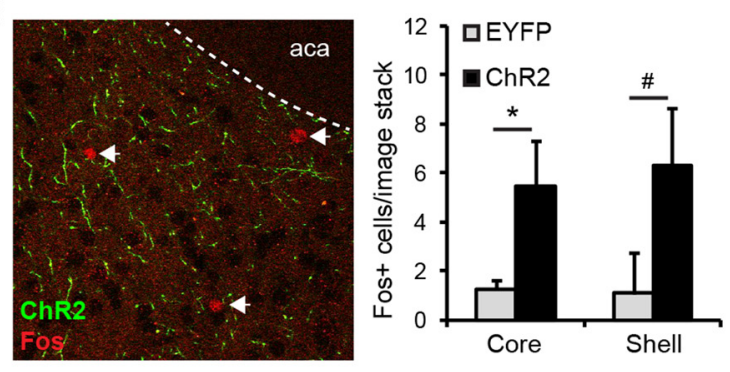

C
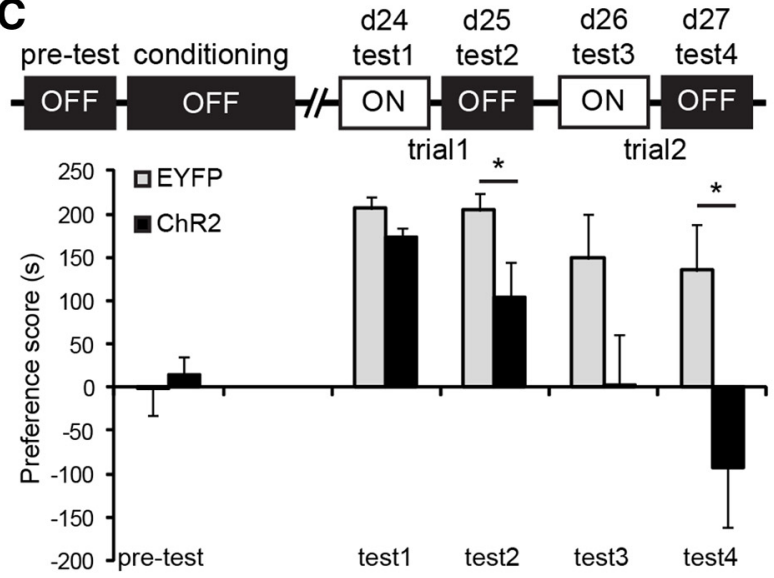

trial1

trial2

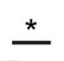

*

test5

OFF

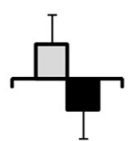

D
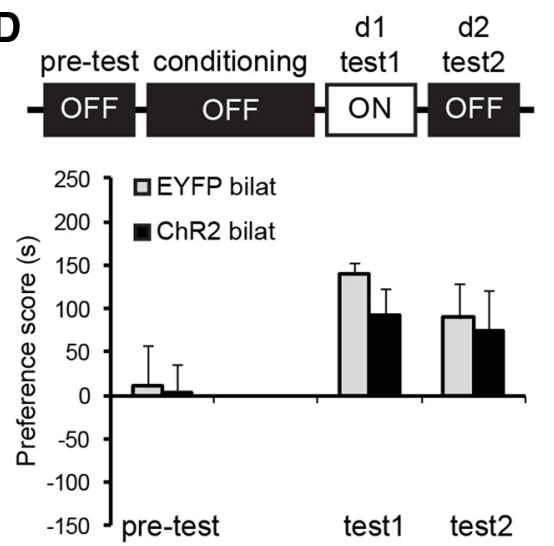

test5
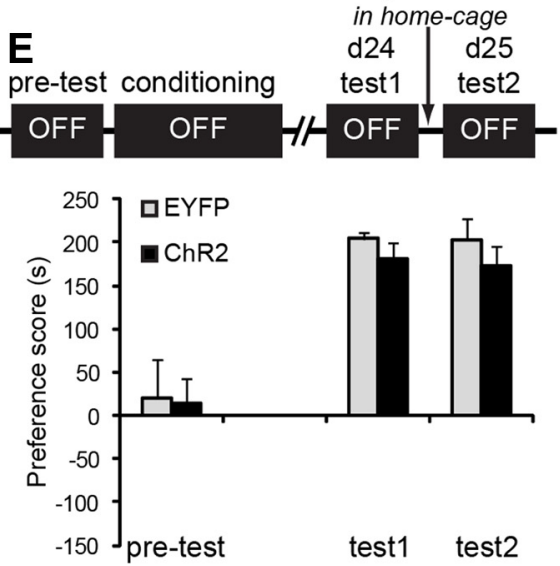

test3 test4

Figure 4. Activation of pyramidal cells specifically attenuated remote CPP memory, without affecting memory reconsolidation. $A$, In wild-type mice infused with AAV-CaMKII::EYFP virus, minimal colocalization of GAD67 ${ }^{+}$GABAergic interneurons within the EYFP ${ }^{+}$cell population (5.6\%) was observed. $\boldsymbol{B}$, Left, Example of Fos expression in the Nucleus accumbens after ChR2 mice received optic stimulation in their home-cage. Green structures represent ChR2 ${ }^{+}$projection fibers. aca, Anterior commissure anterior part. Right, Optic activation of vmPFC pyramidal cells increased the number of $\mathrm{Fos}^{+}$cells in the medial region of the nucleus accumbens ${ }^{*} p=0.028,{ }^{\#} p=0.054$. ChR2, $n=7$, EYFP, $n=6$. C, In mice that were only tested for remote CPP memory, we confirmed that pyramidal cell activation did not have an acute effect on CPP memory (Test $1+3$ ), but impaired memory expression the following day (Test $2+4$ ). ${ }^{*} p<0.05$ compared with control group. ChR2, $n=10$; EYFP, $n=9$. D. Similar to unilateral ChR2 expression, mice with bilateral expression of ChR2 and EYFP did not differ in expression of recent CPP memory. ChR2, $n=8$; EYFP, $n=8$. $\boldsymbol{E}$, Optic stimulation of mice in their home-cage $1 \mathrm{~h}$ after remote CPP memory retrieval (Test 1 ) did not affect preference for the cocaine-associated context the following day (Test 2). ChR2, $n=8$; EYFP, $n=7$. All graphs represent mean \pm SEM.

compared with Trial 1, but activation of pyramidal cells completely abolished preference in the ChR2 group. Similar to the first CPP experiment (Fig. $3 A$ ), we found that optic stimulation did not acutely reduce conditioned cocaine seeking during the light on tests (Test 1 and Test 3: $p>0.05$ compared with EYFP group), but impaired the expression of CPP memory the following days compared with control mice (Test 2: $t_{(17)}=2.26, p=$ 0.037 ; Test $\left.4: t_{(17)}=2.62, p=0.018\right)$. This confirms that increased pyramidal cell activity attenuated cocaine CPP memory specifically at the remote time-point and that the CaMKII::Cre mice and
CaMKII-driven promoter virus approach produced the same behavioral effect. Although in Test 4 ChR 2 mice did not have a significant preference for the salinepaired context $\left(t_{(8)}=1.29, p=0.232\right)$, the data suggest that these mice may have developed an aversion for the cocaine context due to prior activation of vmPFC pyramidal cells. To determine whether this is true, we reassessed preference scores on day 28 (Test 5) without optical stimulation. Again, ChR2 mice did not show a significant preference for the saline context $\left(t_{(8)}=0.97, p=0.357\right)$ and no longer differed from the control group $\left(t_{(17)}=1.53, p=0.143\right)$, suggesting that the animals did not develop an aversion for the cocaine-associated context.

The above experiments demonstrate that unilateral activation of vmPFC pyramidal cells was sufficient to attenuate remote cocaine CPP memory. To determine whether the lack of effect on recent CPP memory was due to activation of an insufficient number of vmPFC pyramidal cells, we bilaterally injected ChR2 and control virus in the vmPFC and studied the effect of optic activation on day 1 (light on) and 2 (light off) after conditioning (Fig. 4D). We found no significant group, light, or group $\times$ light interaction $\left(F_{(1,14)}=0.654\right.$, $p=0.432$ ), showing that similar to unilateral activation, bilateral activation of vmPFC pyramidal cells did not affect recent cocaine CPP memory.

We speculated that increased pyramidal cell firing during the remote light on test (Figs. 3, 4C) may have facilitated the formation of an inhibitory extinction memory, thereby suppressing conditioned cocaine seeking the subsequent day. However, optic activation of vmPFC pyramidal cells during Test 1 may also have disrupted reconsolidation of the cocaine contextual memory. Upon initial memory retrieval, memories are thought to enter a labile state and need to be reconsolidated into a stabile memory for subsequent memory retrieval (Nader et al., 2000). Previous studies indicate that reconsolidation of conditioned fear and CPP memory is sensitive to disruption when interventions are performed $1 \mathrm{~h}$ after retrieval (Monfils et al., 2009; Xue et al., 2012). We set out to determine whether pyramidal cell activation affected reconsolidation mechanisms by stimulating these cells $1 \mathrm{~h}$ after the first remote $\mathrm{CPP}$ test. To test this, we trained $\mathrm{ChR} 2$ and control mice and reactivated their cocaine CPP memory in the absence of optic stimulation at day 24 after training (Fig. 4E). One hour after the CPP test, we optically activated vmPFC pyramidal cells for $5 \mathrm{~min}$ while mice remained in their home-cage. The next day, we reassessed cocaine CPP memory in the absence of light stimulation. Statistical analysis revealed no group, test, or group $\times$ test inter- 
action $\left(F_{(1,13)}=0.88 ; p=0.772\right)$. This experiment indicates that pyramidal cell activation did not suppress expression of remote-conditioned cocaine memory by altering memory reconsolidation mechanisms, but most likely by facilitating extinction upon non-reinforced exposure to the cocaine-associated context.

Optic inhibition of pyramidal cell firing We bilaterally expressed eNpHR3.0 fused to EYFP in vmPFC pyramidal cells to enable sustained cell-selective optic inhibition of spiking activity (Zhang et al., 2007; Goshen et al., 2011). In acute brain slices of CaMKII-Cre mice infused with Creinducible eNpHR3.0 virus, we confirmed that a pulse of green light $(532 \mathrm{~nm}, 10$ $\mathrm{mW}, 0.5 \mathrm{~s}$ pulse) induced a time-locked outward current in eNpHR3.0-expressing pyramidal cells (Fig. 5A) when cells were voltage clamped at $-70 \mathrm{~V}$. Moreover, when we depolarized cells $(-55 \mathrm{mV})$ to evoke trains of action potentials, green light pulses reliably prevented spike firing (Fig. $5 B, C, t_{(3)}=10.1, p=0.002$ ), thereby providing an efficient tool to silence pyramidal cells during recall of cocaine-CPP memory.

\section{Inhibition of pyramidal cells during expression of conditioned-cocaine memory}

Mice were infused with eNpHR3.0-EYFP or EYFP control virus and trained for cocaine-CPP. Similar to the CPP experiment described above, we tested all mice in the presence and absence of optic stimulation, but independent groups of mice were used to assess the effect of inhibition on recent (CaMKII-Cre mice with Cre inducible virus) and remote (wild-type mice with CaMKII promoter-driven virus) memory time-points (Fig. 5D,E). Although both groups showed a significant place preference at the recent CPP memory tests, repeated-measures ANOVA revealed a significant light $\times$ group interaction $\left(F_{(1,22)}=10.1 ; p=0.004\right)$. Additional analysis demonstrated a significant difference between eNphR3.0 and control group at Test $1\left(t_{(22)}=2.45, p=\right.$ $0.025)$, but not at Test $2\left(t_{(22)}=-1.18, p=0.249\right)$. Hence, the suppressive effect of pyramidal cell inhibition in Test 1 was completely reversible. Similar to the ChR2 experiments, locomotor activity did not differ between groups during both tests (light $X$ group: $\left.F_{(1,22)}=0.89, p=0.355\right)$. In contrast, at $24 \mathrm{~d}$ after training, inhibition of pyramidal cell activity had no effect on preference scores (group $\times$ light interaction: $F_{(1,14)}=0.004$.; $p=0.953$ ). Thus, firing of vmPFC pyramidal cells supported expression of recent, but not remote, cocaine CPP memory. To determine whether pyramidal cell activity is required for the formation of extinction memory after prolonged abstinence, we exgroup. All graphs show mean \pm SEM.
B
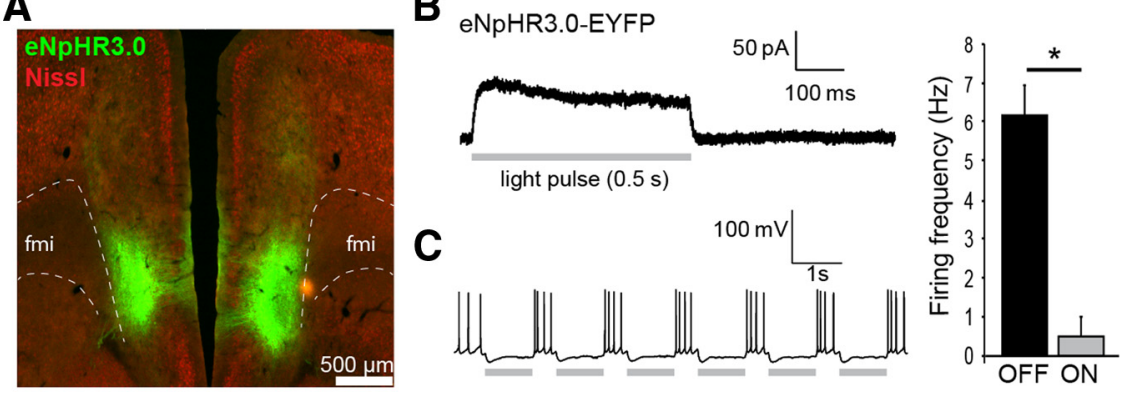

D d1

d2 $\quad E$

pre-test conditioning

d24

d25

test2 OFF
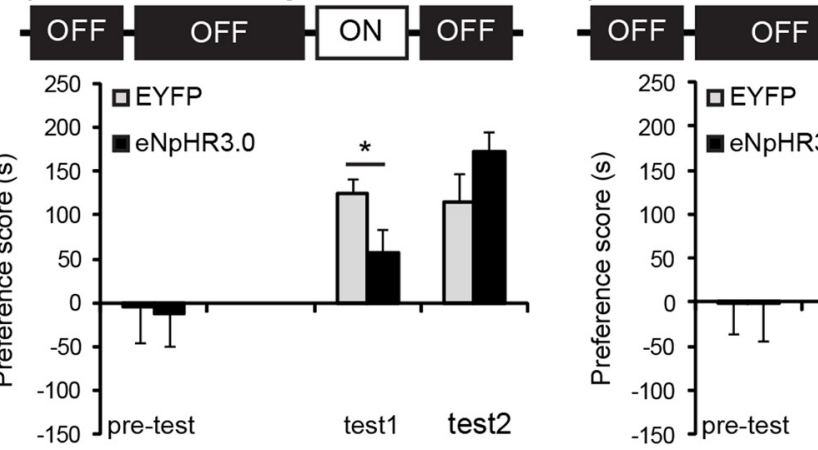

test1

test2

OFF

$F$

ext. training ext. test

G

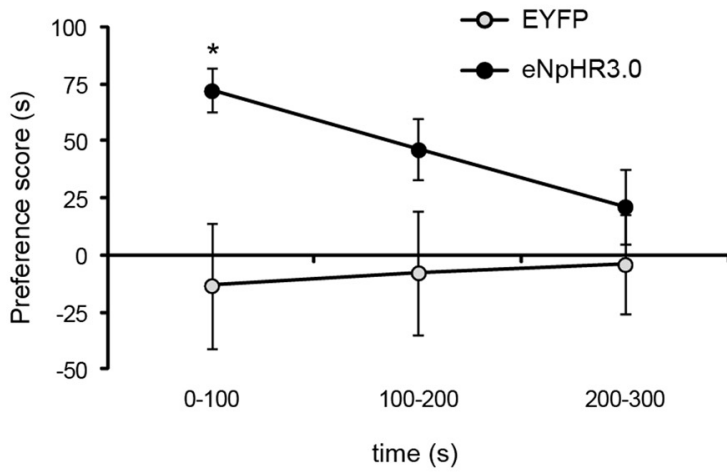

Figure 5. Inhibition of pyramidal cells impaired recall of recent CPP memory and blocked extinction learning. $\boldsymbol{A}$, eNpHR3.0 expression in the vmPFC. $\boldsymbol{B}$, Acute brain slice recordings of eNpHR3.0-expressing pyramidal cells. In a voltage-clamped eNpHR3. $0^{+}$cell, a pulse $(0.5 \mathrm{~s})$ of green light induced a time-locked outward current that restored to baseline at the end of the pulse. $C$, Cells $(n=4)$ were depolarized to $-55 \mathrm{mV}$ to evoke spike firing. Action potentials were reliably blocked in the presence of green light pulses (1 $\mathrm{s}$ ). Graph displays mean spike frequencies \pm SEM during light on and off epochs. ${ }^{*} p=0.002$ compared with light off. $\boldsymbol{D}$, Optic silencing of pyramidal cells acutely attenuated expression of recent CPP memory (Test 1) in a reversible manner. ${ }^{*} p=0.025$ compared with control group. eNpHR3.0, $n=13$; EYFP, $n=11$. $E$, Remote CPP memory was unaffected by inhibition of pyramidal cells. eNpHR3.0, $n=8$; EYFP, $n=8$. $\boldsymbol{F}$, Extinction training in the presence of optic stimulation abolished CPP memory in control mice, whereas CPP levels were unaffected in eNpHR3.0 mice. eNpHR3.0, $n=6$; EYFP, $n=7$. G, Within-session analysis of CPP scores demonstrated that eNpHR3.0 mice had robust place preference at the start of the extinction test, whereas control mice showed no preference for the cocaine context. ${ }^{*} p=0.020$ compared with control

posed groups of the remote CPP tests to an additional extinction training and test protocol. Mice with preference scores $<30 \mathrm{~s}$ at Test $2(n=3)$ were excluded from further testing as extinction had already occurred in these animals. During extinction training on day 26 , we inhibited pyramidal cell activity while mice were confined to the previously saline-paired and cocaine-paired contexts ( 5 min per context, light on in both contexts) in the absence of cocaine reinforcement. The next day, mice were tested for cocaine-CPP memory in the absence of light stimulation to determine whether they had acquired an extinction memory (Fig. $5 F)$. A repeated-measures ANOVA with within factor test (Test 2 
vs ext. test) and between factor group revealed a significant effect of test $\left(F_{(1,11)}=23.6, p=0.001\right)$ and a trend for test $\times$ group interaction $\left(F_{(1,11)}=3.24, p=0.099\right)$. Notably, control mice no longer showed a preference for the cocaine-associated context compared with the saline context $\left(t_{(5)}=0.28, p=0.790\right)$, whereas eNpHR3.0 mice, in which vmPFC pyramidal cell activity was inhibited during extinction training, still had a significant preference for the cocaine context $\left(t_{(5)}=-4.23, p=0.008\right)$. When we examined CPP scores of the extinction test in bins of $100 \mathrm{~s}$ (Fig. $5 G$ ), a significant time-bin $\times$ group interaction $\left(F_{(1,11)}=\right.$ 4.95, $p=0.032$ ) was observed. Additional analysis revealed that CPP scores between groups differed significantly $\left(t_{(11)}=-2.94\right.$, $p=0.020)$ for the first $100 \mathrm{~s}$ of the test only, indicating that at the start of the extinction test, eNPHR3.0 mice showed robust preference for the cocaine context, whereas place preference was absent in control mice. Moreover, it shows that eNpHR3.0 mice were still capable of extinction learning as their CPP scores declined during the last 200 s of the extinction test. Thus, inhibition of pyramidal cells did not affect recall of remote CPP memory, but prevented extinction learning and subsequent suppression of conditioned cocaine seeking.

\section{Discussion}

Using an optogenetics approach, we provide causal evidence for a temporal dynamic role of vmPFC pyramidal cells in expression of a cocaine-associated memory. Activity of these cells is required for recall of a recently acquired cocaine memory, but following prolonged abstinence from cocaine exposure, the same cellular subtype contributes to extinction of conditioned cocaine seeking. Together, our data indicate that reorganization of the circuitry that controls expression of cocaine-associated memory underlies the differential behavioral responses to optic modulation of vmPFC pyramidal cell activity.

The large majority of neurons within the vmPFC region are glutamatergic pyramidal cells and these neurons are thought to have an important function in conditioned drug seeking (Kalivas et al., 2005; Van den Oever et al., 2012). One might expect that increasing and decreasing the activity of these neurons would have opposing behavioral consequences. We did not observe this effect when optically activating and silencing vmPFC pyramidal cells during tests for conditioned cocaine memory. Instead, we show that both activation and inhibition of pyramidal cells could suppress expression of cocaine CPP memory, but that the effect depended on whether cocaine memory was examined during early withdrawal or after a protracted drug-free period. Previously, Koya et al. (2009a) found that pharmacological inactivation of the vmPFC reduces cue-induced cocaine seeking, suggesting that firing of neurons within the vmPFC is required to recall a conditioned cocaine memory. Our data supports this role of the vmPFC and demonstrates that this behavior depends on the activity of pyramidal cells in the vmPFC. However, we found that activity of these cells was required for the expression of recent, but not remote cocaine memory, whereas Koya et al. (2009a) showed that inactivation of the vmPFC impaired the expression of cocaine seeking at a remote time-point (30 d after cocaine self-administration). The discrepancy between these findings may be explained by differences in cell specificity and/or temporal resolution of the intervention approaches (Goshen et al., 2011). Alternatively, it might be due to differences in the strength of the conditioned cocaine memory; our study and that of Koya et al. (2009a) differed in the method of cocaine administration (experimenter vs self-administration, respectively) and the number of cocaine-cue pairings during training $(3 \times 15 \mathrm{~min}$ sessions in our protocol vs $10 \times 6 \mathrm{~h}$ sessions, respectively). Possibly, the requirement of pyramidal cell firing for recall of conditioned-cocaine memory is time-dependent and a function of the strength of the acquisition (learning) of this memory.

Several studies have implicated the vmPFC in the acquisition of an extinction memory that can suppress conditioned cocaine seeking (LaLumiere et al., 2010; LaLumiere et al., 2012) and conditioned fear responses (Milad and Quirk, 2002; Santini et al., 2008). In line with these observations, we found that increased firing of pyramidal cells in the vmPFC was sufficient to extinguish conditioned cocaine seeking after prolonged abstinence and inhibition of pyramidal cells blocked extinction learning. Interestingly, optical excitation of pyramidal cells had no (significant) acute effect on the expression of CPP memory, but impaired recall the following day. As we found that optic stimulation did not affect reconsolidation of the cocaine CPP memory, our data hints to facilitated formation of an extinction memory-trace. This conclusion is corroborated by our observation that vmPFC pyramidal cell activity was required for the formation of an extinction memory. The optical excitation of pyramidal cells in the vmPFC may have changed the strength of connections with target neurons, for instance in the nucleus accumbens shell (Peters et al., 2008a; Pascoli et al., 2012), thereby strengthening the formation of a new memory trace that signals that the cocaineassociated environment is no longer paired with cocaine reward. Although activation of pyramidal cells at the recent memory time-point was ineffective in extinguishing conditioned cocaine seeking, it does not rule out the possibility that recent cocaine CPP memory cannot be extinguished. Rather, it suggests that the remote CPP memory was more susceptible to extinction induced by optical stimulation of vmPFC pyramidal cells, potentially caused by reorganization of the circuitry that controls expression of conditioned cocaine memory. We speculate that this reorganization may have recruited projection targets of vmPFC pyramidal cells that were not involved in expression of the recent cocaine CPP memory. The lack of effect of pyramidal cell activation on recent cocaine memory is in line with observations that pharmacological manipulations that impair vmPFC function do not affect extinction of cocaine seeking within the first days after cocaine exposure (Peters et al., 2008b; Szalay et al., 2012). Moreover, as expression of recent, but not remote, CPP memory depended on the firing of vmPFC pyramidal cells, optically stimulating these cells with ChR2 likely activated neurons that supported conditioned cocaine seeking, thereby potentially overruling extinction mechanisms during early abstinence. Endogenous activation of vmPFC pyramidal cells during recall of recent CPP memory may also explain why optical activation did not further enhance expression at this time-point.

How can pyramidal cells in the vmPFC contribute to recall as well as extinction of a conditioned cocaine memory? Mounting evidence indicates that associative memories are retrieved by only a small proportion of cells in behaviorally relevant brain regions (Han et al., 2007; Reijmers et al., 2007; Mattson et al., 2008; Silva et al., 2009; Liu et al., 2012). For instance, the expression of a heroin-associated contextual memory depends on the activity of $\sim 6 \%$ of cells in the vmPFC (Bossert et al., 2011). Assuming that expression of cocaine-CPP memory is also controlled by only a small proportion of neurons in the vmPFC, it is possible that the same population mediates recall as well as extinction of this memory. Structural remodeling of synapses on pyramidal cells may underlie this process, as it was recently found that conditioning and extinction of a fear memory are associated with opposing 
effects on spine elimination and formation on the same dendritic branch of neurons in the frontal association cortex (Lai et al., 2012). Also, differences in firing patterns of pyramidal cells may underlie the differential behavioral outcomes, as was previously observed during the expression and extinction of morphine CPP (Sun et al., 2011). Alternatively, the process of recall and extinction may be controlled by two distinct pyramidal cell populations in the vmPFC. Apart from differences in morphology and firing characteristics, these populations may differ in the neuronal input they receive, as well as their output targets, and may thereby have a differential effect on behavioral responding. Future studies should point out whether recall and extinction are regulated by the same or different pyramidal cell populations in the vmPFC.

Several methodological issues should be considered with the interpretation of our results. First, it is possible that optic modulation of pyramidal cells in the vmPFC induced an anhedonialike state that caused the animals to avoid the cocaine-associated context. However, this can be ruled out because we altered activity of pyramidal cells throughout the entire CPP test, and, therefore, the mice also received stimulation when they spent time in the saline-paired context. Second, differences in motor activity also cannot account for the reduced time spent in the cocaineassociated context, as motor activity did not differ between control and experimental groups during optic stimulation tests. We did observe a small, but significant, increase in activity during light on tests in all groups, but this likely reflects an arousal effect evoked by the presence of laser-light in the CPP box or by novelty of the test conditions. Third, stimulation-induced extinction may have occurred specifically at the remote memory time-point because the CPP memory was weaker after prolonged abstinence. Arguing against this option is the observation that CPP scores at the remote test were generally higher than CPP scores at the recent memory tests (compare Test 1 in Fig. 3 and Fig. 4C). A time-dependent increase in responding to cocaine-associated cues during periods of abstinence is a well described phenomenon and often referred to as incubation of cocaine craving (Grimm et al., 2001; Bossert et al., 2005).

\section{Concluding remarks}

Previous research established the involvement of the vmPFC in expression of drug-seeking responses elicited by drug-associated cues. Our data extends these reports by demonstrating that pyramidal cells in the vmPFC have a dual, time-dependent role in controlling conditioned cocaine-seeking behavior, pointing to reorganization of the circuit that mediates expression of cocaineassociated memories over time. This is a crucial first step toward a more detailed understanding of the role of the vmPFC circuitry in addictive behavior. Future studies should identify the neuronal sources of input and output targets of the vmPFC, as well as local vmPFC circuitry adaptations that contribute to retrieval and extinction of cocaine-associated memories, with the perspective to develop more effective treatment options that are able to suppress conditioned cocaine-seeking responses.

\section{References}

Beaulieu C (1993) Numerical data on neocortical neurons in adult rat, with special reference to the GABA population. Brain Res 609:284-292. CrossRef Medline

Bossert JM, Ghitza UE, Lu L, Epstein DH, Shaham Y (2005) Neurobiology of relapse to heroin and cocaine seeking: an update and clinical implications. Eur J Pharmacol 526:36-50. CrossRef Medline

Bossert JM, Stern AL, Theberge FR, Cifani C, Koya E, Hope BT, Shaham Y (2011) Ventral medial prefrontal cortex neuronal ensembles mediate context-induced relapse to heroin. Nat Neurosci 14:420-422. CrossRef Medline

Childress AR, Mozley PD, McElgin W, Fitzgerald J, Reivich M, O’Brien CP (1999) Limbic activation during cue-induced cocaine craving. Am J Psychiatry 156:11-18. Medline

Goshen I, Brodsky M, Prakash R, Wallace J, Gradinaru V, Ramakrishnan C, Deisseroth K (2011) Dynamics of retrieval strategies for remote memories. Cell 147:678-689. CrossRef Medline

Grant S, London ED, Newlin DB, Villemagne VL, Liu X, Contoreggi C, Phillips RL, Kimes AS, Margolin A (1996) Activation of memory circuits during cue-elicited cocaine craving. Proc Natl Acad Sci U S A 93:1204012045. CrossRef Medline

Grimm JW, Hope BT, Wise RA, Shaham Y (2001) Neuroadaptation. Incubation of cocaine craving after withdrawal. Nature 412:141-142. CrossRef Medline

Han JH, Kushner SA, Yiu AP, Cole CJ, Matynia A, Brown RA, Neve RL, Guzowski JF, Silva AJ, Josselyn SA (2007) Neuronal competition and selection during memory formation. Science 316:457-460. CrossRef Medline

Heidbreder CA, Groenewegen HJ (2003) The medial prefrontal cortex in the rat: evidence for a dorso-ventral distinction based upon functional and anatomical characteristics. Neurosci Biobehav Rev 27:555-579. CrossRef Medline

Johansen JP, Hamanaka H, Monfils MH, Behnia R, Deisseroth K, Blair HT, LeDoux JE (2010) Optical activation of lateral amygdala pyramidal cells instructs associative fear learning. Proc Natl Acad Sci U S A 107:1269212697. CrossRef Medline

Kalivas PW, Volkow N, Seamans J (2005) Unmanageable motivation in addiction: a pathology in prefrontal-accumbens glutamate transmission. Neuron 45:647-650. CrossRef Medline

Koya E, Uejima JL, Wihbey KA, Bossert JM, Hope BT, Shaham Y (2009a) Role of ventral medial prefrontal cortex in incubation of cocaine craving. Neuropharmacology 56 Suppl 1:177-185. CrossRef Medline

Koya E, Golden SA, Harvey BK, Guez-Barber DH, Berkow A, Simmons DE, Bossert JM, Nair SG, Uejima JL, Marin MT, Mitchell TB, Farquhar D, Ghosh SC, Mattson BJ, Hope BT (2009b) Targeted disruption of cocaine-activated nucleus accumbens neurons prevents context-specific sensitization. Nat Neurosci 12:1069-1073. CrossRef Medline

Lai CS, Franke TF, Gan WB (2012) Opposite effects of fear conditioning and extinction on dendritic spine remodelling. Nature 483:87-91. CrossRef Medline

LaLumiere RT, Niehoff KE, Kalivas PW (2010) The infralimbic cortex regulates the consolidation of extinction after cocaine self-administration. Learn Mem 17:168-175. CrossRef Medline

LaLumiere RT, Smith KC, Kalivas PW (2012) Neural circuit competition in cocaine-seeking: roles of the infralimbic cortex and nucleus accumbens shell. Eur J Neurosci 35:614-622. CrossRef Medline

Liu X, Ramirez S, Pang PT, Puryear CB, Govindarajan A, Deisseroth K, Tonegawa S (2012) Optogenetic stimulation of a hippocampal engram activates fear memory recall. Nature 484:381-385. Medline

Mattson BJ, Koya E, Simmons DE, Mitchell TB, Berkow A, Crombag HS, Hope BT (2008) Context-specific sensitization of cocaine-induced locomotor activity and associated neuronal ensembles in rat nucleus accumbens. Eur J Neurosci 27:202-212. Medline

Milad MR, Quirk GJ (2002) Neurons in medial prefrontal cortex signal memory for fear extinction. Nature 420:70-74. CrossRef Medline

Monfils MH, Cowansage KK, Klann E, LeDoux JE (2009) Extinctionreconsolidation boundaries: key to persistent attenuation of fear memories. Science 324:951-955. CrossRef Medline

Nader K, Schafe GE, LeDoux JE (2000) The labile nature of consolidation theory. Nat Rev Neurosci 1:216-219. CrossRef Medline

Ovari J, Leri F (2008) Inactivation of the ventromedial prefrontal cortex mimics re-emergence of heroin seeking caused by heroin reconditioning. Neurosci Lett 444:52-55. CrossRef Medline

Pascoli V, Turiault M, Lüscher C (2012) Reversal of cocaine-evoked synaptic potentiation resets drug-induced adaptive behaviour. Nature 481:7175. Medline

Peters J, LaLumiere RT, Kalivas PW (2008a) Infralimbic prefrontal cortex is responsible for inhibiting cocaine seeking in extinguished rats. J Neurosci 28:6046-6053. CrossRef Medline

Peters J, Vallone J, Laurendi K, Kalivas PW (2008b) Opposing roles for the ventral prefrontal cortex and the basolateral amygdala on the spontane- 
ous recovery of cocaine-seeking in rats. Psychopharmacology 197:319326. CrossRef Medline

Peters J, Kalivas PW, Quirk GJ (2009) Extinction circuits for fear and addiction overlap in prefrontal cortex. Learn Mem 16:279-288. CrossRef Medline

Reijmers LG, Perkins BL, Matsuo N, Mayford M (2007) Localization of a stable neural correlate of associative memory. Science 317:1230-1233. CrossRef Medline

Rogers JL, Ghee S, See RE (2008) The neural circuitry underlying reinstatement of heroin-seeking behavior in an animal model of relapse. Neuroscience 151:579-588. CrossRef Medline

Santini E, Quirk GJ, Porter JT (2008) Fear conditioning and extinction differentially modify the intrinsic excitability of infralimbic neurons. J Neurosci 28:4028-4036. CrossRef Medline

Sesack SR, Deutch AY, Roth RH, Bunney BS (1989) Topographical organization of the efferent projections of the medial prefrontal cortex in the rat: an anterograde tract-tracing study with Phaseolus vulgaris leucoagglutinin. J Comp Neurol 290:213-242. CrossRef Medline

Silva AJ, Zhou Y, Rogerson T, Shobe J, Balaji J (2009) Molecular and cellular approaches to memory allocation in neural circuits. Science 326:391-395. CrossRef Medline

Somogyi P, Tamás G, Lujan R, Buhl EH (1998) Salient features of synaptic organisation in the cerebral cortex. Brain Res Brain Res Rev 26:113-135. CrossRef Medline

Sparta DR, Stamatakis AM, Phillips JL, Hovelsø N, van Zessen R, Stuber GD (2012) Construction of implantable optical fibers for long-term optogenetic manipulation of neural circuits. Nat Protoc 7:12-23. CrossRef Medline

Stuber GD, Sparta DR, Stamatakis AM, van Leeuwen WA, Hardjoprajitno JE, Cho S, Tye KM, Kempadoo KA, Zhang F, Deisseroth K, Bonci A (2011) Excitatory transmission from the amygdala to nucleus accumbens facilitates reward seeking. Nature 475:377-380. CrossRef Medline

Sun N, Chi N, Lauzon N, Bishop S, Tan H, Laviolette SR (2011) Acquisition, extinction, and recall of opiate reward memory are signaled by dynamic neuronal activity patterns in the prefrontal cortex. Cereb Cortex 21:26652680. CrossRef Medline

Szalay JJ, Jordan CJ, Kantak KM (2012) Neural regulation of the time course for cocaine-cue extinction consolidation in rats. Eur J Neurosci
Tsai HC, Zhang F, Adamantidis A, Stuber GD, Bonci A, de Lecea L, Deisseroth K (2009) Phasic firing in dopaminergic neurons is sufficient for behavioral conditioning. Science 324:1080-1084. CrossRef Medline

Tye KM, Prakash R, Kim SY, Fenno LE, Grosenick L, Zarabi H, Thompson KR, Gradinaru V, Ramakrishnan C, Deisseroth K (2011) Amygdala circuitry mediating reversible and bidirectional control of anxiety. Nature 471:358-362. CrossRef Medline

Van den Oever MC, Goriounova NA, Li KW, Van der Schors RC, Binnekade R, Schoffelmeer AN, Mansvelder HD, Smit AB, Spijker S, De Vries TJ (2008) Prefrontal cortex AMPA receptor plasticity is crucial for cueinduced relapse to heroin-seeking. Nat Neurosci 11:1053-1058. CrossRef Medline

Van den Oever MC, Spijker S, Smit AB, De Vries TJ (2010a) Prefrontal cortex plasticity mechanisms in drug seeking and relapse. Neurosci Biobehav Rev 35:276-284. CrossRef Medline

Van den Oever MC, Lubbers BR, Goriounova NA, Li KW, Van der Schors RC, Loos M, Riga D, Wiskerke J, Binnekade R, Stegeman M, Schoffelmeer AN, Mansvelder HD, Smit AB, De Vries TJ, Spijker S (2010b) Extracellular matrix plasticity and GABAergic inhibition of prefrontal cortex pyramidal cells facilitates relapse to heroin seeking. Neuropsychopharmacology 35:2120-2133. CrossRef Medline

Van den Oever MC, Spijker S, Smit AB (2012) The synaptic pathology of drug addiction. Adv Exp Med Biol 970:469-491. CrossRef Medline

van Zessen R, Phillips JL, Budygin EA, Stuber GD (2012) Activation of VTA GABA neurons disrupts reward consumption. Neuron 73:1184-1194. CrossRef Medline

Voorn P, Vanderschuren LJ, Groenewegen HJ, Robbins TW, Pennartz CM (2004) Putting a spin on the dorsal-ventral divide of the striatum. Trends Neurosci 27:468-474. CrossRef Medline

Xue YX, Luo YX, Wu P, Shi HS, Xue LF, Chen C, Zhu WL, Ding ZB, Bao YP, Shi J, Epstein DH, Shaham Y, Lu L (2012) A memory retrievalextinction procedure to prevent drug craving and relapse. Science 336: 241-245. CrossRef Medline

Zhang F, Aravanis AM, Adamantidis A, de Lecea L, Deisseroth K (2007) Circuit-breakers: optical technologies for probing neural signals and systems. Nat Rev Neurosci 8:577-581. CrossRef Medline 